\title{
PENGARUH EMPLOYEE RETENTION TERHADAP TURNOVER INTENTION DAN KINERJA KARYAWAN PADA PT. BANK RAKYAT INDONESIA UNIT LUBUK BUAYA CABANG PADANG
}

\author{
Dewi Ria Purnama, Riri Mayliza \\ Sekolah Tinggi Ilmu Ekonomi KBP \\ dewiriapurnama92@gmail.com \\ ririmayliza@akbpstie.ac.id
}

\begin{abstract}
When a company loses employees, the company also loses its ability, experience and "corporate memory". It is also an important issue for management, because it will affect productivity, profitability, and quality of service and product quality. For employees, a high turnover rate will affect employee morale, relationships between employees and job security. The cost of replacing employees will also increase, this relates to the costs of employee recruitment and training. Turnover problems can be overcome through various activities that are pro-active towards Stratari Employee Retention: In this study describes that the sample used is the same as the population of 33 people, with the dependent variable turnover intention and employee performance while the independent variable is employee retention. In the results of the study that the employee retention variable has a positive and significant turnover intention. Whereas for employee retention has a positive and significant effect on employee performance.
\end{abstract}

Keyword: Employee Retention, Turnover Intention, Employee Perfomance

\section{PENDAHULUAN}

Sumber daya manusia merupakan elemen organisasi yang sangat penting. Sumber daya manusia merupakan pilar utama sekaligus penggerak roda organisasi dalam upaya mewujudkan visi dan misinya. Karenanya harus dipastikan sumber daya ini dikelola dengan sebaik mungkin agar mampu memberikan kontribusi secara optimal. Maka diperlukanlah sebuah pengelolaan secara sistematis dan terencana agar tujuan yang diinginkan dimasa sekarang dan masa depan bisa tercapai yang sering disebut sebagai manajemen sumber daya amanusia. Tujuan manajemen sumber daya manusia adalah mengelola atau mengembangkan kompetensi personil agar mampu merealisasikan misi organisasi dalam rangka mewujudkan visi.

Pemeliharaan Karyawan atau Retensi karyawan/Employee Retention merupakan kemampuan perusahaan untuk mempertahankan karyawan 
potensial yang dimiliki perusahaan untuk tetap loyal terhadap perusahaan. Pengembangan program Employee Retention haruslah merupakan komponen yang krusial bagi Perusahaan. Jika Employee Retention buruk, maka akan meningkatkan employee turnover yang secara negatif mempunyai dampak terhadap pelayanan terhadap pelanggan, standar produksi kerja dan profitability. Secara umum, hubungan antara Employee Retention terhadap kinerja sangatlah kompleks, terdapat bukti bahwa kinerja dapat menurun jika Employee Retention karyawan buruk dan ada kemungkinan terdapat stagnasi karyawan jika turnover terlalu rendah (Abelson dan Baysinger, 1984 serta Glebbek dan Back, 2004).

Turnover intention atau keinginan pindah tempat kerja merupakan keinginan seseorang untuk mencari pekerja lebih baik dan meninggalkan pekerjaan nya saat ini. Keinginan berpindah kerja berbeda dengan turnover akan tetapi memiliki arti yang hampir sama.Karyawan yang ingin keluar dari pekerjaan nya , biasanya tidak selalu dapat terlakasana karna tidak memiliki kemampuan untuk dapat keluar dari pekerjaan nya atau takut mendapatkan pekerjaan yang lebih buruk dari sebelum nya (Amelia,2010)

Turnover intention merupakan masalah yang sering dihadapi oleh perusahaan atau organisasi hal itu disebabkan oleh beberapa faktor seperti : kondisi lingkungan pekerjaan yang tidak mendukung, pelanggaran terhadap kontrak psikologis, beban kerja yang tidak sesuai dengan pekerjaan, dan stress kerja yang merupakn stimulan atau pendorong seorang individu untuk keluar dari perusahaan ( Elizabeth ,2012)

Bank Rakyat Indonesia (BRI) adalah salah satu usaha perbankan terbesar milik pemerintah Indonesia yang berdiri sejak 16 Desember 1895 yang memiliki jumlah Sumber Daya Manusia (SDM) yang cukup banyak dan berkualitas. Tingkat persaingan kerja yang semakin besar mendorong karyawan untuk lebih meningkatkan kinerjanya dan memberikan kinerja yang terbaik. Hampir semua karyawan mendambakan untuk mendapatkan karier , karna pada dasarnya karyawan menginginkan kehidupan yang lebih baik dari sebelum nya seperti pendapatan yang tinggi, bonus dan fasilitas yang di berikan oleh perusahaan.

Hasil penilaian kinerja menunjukan apakah sumber daya manusia (karyawan/pegawai) pada perusahaan tersebut sudah memenuhi target atau sasaran baik secara kualitas maupun kuantitas yang dikehendaki oleh PT. Bank Rakyat Indonesia, sehingga perusahaan dapat memberikan jenjang karier yang sesuai dengan hasil penilaian kinerja dan peraturan yang berlaku.

Bank Rakyat Indonesia memiliki jumlah karywan wanita dan pria yg cukup banyak, karyawan wanita sama seperti karyan pria memiliki kesempatan yang sama dalam bekerja, namun karyawan wanita memiliki kebutuhan yang berbeda dengan karyawan pria sehingga karyawan wanita lebih memperoleh hak - hak khusus seperti yang di atur dalm undang undang no 13 tahun 2003 mengenai perlindungan terhadap tenaga kerja wanita. Namum tidak sedikit karyawan wanita yang mengundurkan diri .

Ketika perusahaan kehilangan karyawan, maka perusahaan juga kehilangan kemampuan, pengalaman, dan "memori perusahaan". Hal tersebut 
juga merupakan isu yang penting bagi manajemen, karena akan mempengaruhi produktivitas, profitability, dan kualitas dari pelayanan serta kualitas produk. Bagi karyawan, tingkat turnover yang tinggi akan berpengaruh terhadap moral karyawan, hubungan antar karyawan dan keamanan kerja. Biaya penggantian karyawan juga akan meningkat, hal ini berhubungan dengan biaya rekrutmen karyawan dan pelatihan. Masalah turnover dapat diatasi melalui berbagai kegiatan yang pro-aktif terhadap stratagi Employee Retention: kebijakan kerja yang meningkatkan komitmen dan loyalitas karyawan (Lockhead \& Stephen, 2004).

Kinerja karyawan adalah hasil secara kualitas dan kuantitas yang dicapai oleh seseorang karyawan dalam melaksanakan tugasnya sesuai dengan tanggung jawab yang diberikan kepadanya (Mangkunegara,2001). Kinerja dapat diartikan sebagai hasil kerja yang dicapai oleh seseorang atau kelompok organisasi dalam waktu tertentu . Dalam beberapa literatur , istilah kinerja dikenal pula dengan istilah prestasi kerja.

Rumusan Masalah

Dari latar belakang yang telah diuraikan, maka rumusan masalah dalam penelitian Pengaruh employee retention terhadap turnover intention dan kinerja karyawan adalah sebagai berikut :

1. Apakah Employee Retention berpengaruh terhadap Turnover Intention pada PT. Bank Rakyar Indonesia?

2. Apakah Employee Retention berpengaruh terhadap Kinerja karyawan pada PT. Bank Rakyat Indonesia?

Tujuan Penelitian

Berdasarkan rumusan masalah yang di atas, maka tujuan penelitian ini adalah sebagai berikut :

1. Untuk menguji Pengaruh Employee Retention terhadap Turnover Intention pada Pt. Bank Rakyat Indonesia.

2. Untuk menguji pengaruh Employee Retention terhadap Kinerja terhadap Pt. Bank Rakyat Indonesia.

\section{Turnover Intention}

Dalam teori perilaku terencana, faktor utama dari suatu perilaku yang ditampilkan individu adalah intensi untuk menampilkan perilaku tertentu. Intensi diasumsikan sebagai faktor motivasional yang mempengaruhi perilaku. Intensi merupakan indikasi seberapa keras seseorang berusaha atau seberapa banyak usaha yang dilakukan untuk menampilkan suatu perilaku. Sebagai aturan umum, semakin keras intensi seseorang untuk terlibat dalam suatu perilaku, semakin besar kecenderungan ia untuk benar-benar melakukan perilaku tersebut.

Intensi untuk berperilaku dapat menjadi perilaku sebenarnya hanya jika perilaku tersebut ada di bawah kontrol individu yang bersangkutan. Individu tersebut memiliki pilihan untuk memutuskan menampilkan perilaku tertentu atau tidak sama sekali. Sampai seberapa jauh individu akan menampilkan perilaku, juga tergantung pada faktor-faktor non motivasional. 
Salah satu contoh dari faktor non motivasional adalah ketersediaan kesempatan dan sumber yang dimiliki (misal, uang, waktu, dan bantuan dari pihak lain). Faktor motivasional dan non motivasional mencerminkan kontrol aktual terhadap perilaku. Jika kesempatan dan sumber-sumber yang dimiliki tersedia dan terdapat intensi untuk menampilkan perilaku, maka kemungkinan perilaku itu muncul, sangatlah besar. Dengan kata lain, suatu perilaku akan muncul, jika terdapat motivasi (intensi) dan kemampuan (kontrol perilaku).

Arti intensi adalah niat atau keinginan yang timbul pada individu untuk melakukan sesuatu. Sementara turnover adalah berhentinya seseorang karyawan dari tempatnya bekerja secara sukarela. Dapat didefinisikan bahwa intensi turnover adalah kecenderungan atau niat karyawan untuk berhenti bekerja dari pekerjaannya secara sukarela menurut pilihannya sendiri. Intensi turnover ada di bawah kontrol individu, sehingga dapat memberikan hasil penelitian yang lebih cepat dan relatif mudah diprediksi dibanding perilaku turnover-nya. Menurut Ajzen (1991) ada beberapa faktor yang berpengaruh terhadap terjadinya turnover, diantaranya adalah faktor eksternal yakni pasar tenaga kerja, faktor institusi yakni kondisi ruang kerja, upah, keterampilan kerja, dan supervisi, karakteristik personal dari karyawan seperti intelegensi, sikap, masa lalu, jenis kelamin, minat, umur, dan lama bekerja serta reaksi individu terhadap pekerjaannya. Intensi turnover merupakan hasil (outcome) yang ditunjukkan oleh individu dalam perusahaan berupa perilaku sebagai akibat dari adanya ketidakpuasan yang dirasakan oleh karyawan atas pekerjaan yang mereka lakukan. Hughes et.al. mengungkapkan ada tiga faktor seorang karyawan memiliki keinginan untuk keluar dari sebuah perusahaan. Pertama, adanya anggapan dari individu-individu yang telah berada pada posisi terbaik bahwa mereka tidak akan lama lagi berada pada posisi tersebut, kedua, menurunnya kapabilitas dan tingkat kesuksesan karyawan karena penambahan beban kerja yang diberikan sebagai akibat dari pelaksanaan downsizing, serta ketiga, bagi organisasi yang melaksanakan perampingan struktur organisasi sangat sulit dari segi waktu atau tertundanya proses perekrutan karyawan baru yang dibutuhkan untuk memperbaiki eksistensi keberlangsungan hidup perusahaan. Turnover yang dapat dikontrol adalah karyawan yang meninggalkan organisasi secara sukarela (voluntary), sementara itu turnover yang tidak terkontrol adalah karena alasan yang tidak sukarela (involuntary) seperti pengunduran diri, meninggal, atau mengikuti kepindahan suami/isteri. Selanjutnya, turnover dikatakan fungsional apabila merupakan permulaan dari karyawan untuk memberikan hasil bagi organisasi, atau disfungsional apabila tidak memberikan hasil bagi organisasi. 


\section{Kinerja}

Hani Handoko (2002) mengistilahkan kinerja (performance) dengan prestasi kerja yaitu proses organisasi mengevaluasi atau menilai prestasi kerja karyawan. Berikut ini adalah beberapa pengertian kinerja oleh beberapa pakar yang dikutip oleh Bambang Guritno dan Waridin (2005) yaitu:

a. Menurut Winardi (1992) kinerja merupakan konsep yang bersifat universal yang merupakan efektivitas operasional suatu organisasi, bagian organisasi ,dan bagian karyawannya berdasar standar dan kriteria yang telah ditetapkan sebelumnya, karena organisasi pada dasarnya dijalankan oleh manusia, maka kinerja sesungguhnya merupakan perilaku manusia dalam memainkan peran yang mereka lakukan dalam suatu organisasi untuk memenuhi standar perilaku yang telah ditetapkan agar membuahkan tindakan dan hasil yang diinginkan.

2. Menurut Gomes (2000) kinerja merupakan catatan terhadap hasil produksi dari sebuah pekerjaan tertentu atau aktivitas tertentu dalam periode waktu tertentu.

Sopiah (2008) menyatakan lingkungan juga bisa mempengaruhi kinerja seseorang. Situasi lingkungan yang kondusif, misalnya dukungan dari atasan, teman kerja, sarana dan prasarana yang memadai akan menciptakan kenyamanan tersendiri dan akan memacu kinerja yang baik. Sebaliknya, suasana kerja yang tidak nyaman karena sarana dan prasarana yang tidak memadai, tidak adanya dukungan dari atasan, dan banyak terjadi konflik akan memberi dampak negatif yang mengakibatkan kemerosotan pada kinerja seseorang. Sedangkan kinerja karyawan menurut Henry Simamora (2004) dalam Dito (2010) adalah tingkat hasil kerja karyawan dalam pencapaian persyaratan pekerjaan yang diberikan. Menurut Rita Swietenia (2009) manfaat kinerja pegawai antara lain adalah untuk menganalisa dan mendorong efisiensi produksi, untuk menentukan target atau sasaran yang nyata, lalu untuk pertukaran informasi antara tenaga kerja dan manajemen yang berhubungan terhadap masalah-masalah yang berkaitan.

Adapun indikator kinerja karyawan menurut Bambang Guritno dan Waridin (2005) adalah sebagai berikut:

a. Mampu meningkatkan target pekerjaan

b. Mampu menyelesaikan pekerjaan tepat waktu

c. Mampu menciptakan inovasi dalam menyelesaikan pekerjaan

d. Mampu menciptakan kreativitas dalam menyelesaikan pekerjaan

e. Mampu meminimalkan kesalahan pekerjaan

\section{Employee Retention}

Employee Retention atau retensi karyawan merupakan kemampuan perusahaan untuk mempertahankan karyawan potensial yang dimiliki perusahaan untuk tetap loyal terhadap perusahaan. Tujuan dari retensi karyawan ialah untuk mempertahankan karyawan 
yang dianggap berkualitas yang dimiliki perusahaan selama mungkin, karena karyawan yang berkualitas merupakan harta yang tidak berwujud (intangible asset) yang tak ternilai bagi perusahaan. Jadi jika karyawan yang berkualitas keluar dari perusahaan atas kehendak sendiri, maka hal tersebut merupakan kerugian modal intelektual bagi perusahaan. Para karyawan yang bekerja dalam jangka lama dan loyal akan membawa nilai perusahaan dan pengetahuan tentang berbagai proses organisasional dan diharapkan sensitifitasnya terhadap kebutuhan para pelanggan. Upaya untuk mempertahankan karyawan telah menjadi persoalan utama dalam banyak organisasi. Oleh karena itu sangatlah penting organisasi mengakui bahwa retensi karyawan merupakan perhatian SDM yang berkelanjutan dan tanggung jawab signifikan bagi semua supervisor dan manajer. .

Menurut Hasibuan (2000) pemeliharaan karyawan harus mendapat perhatian yang sungguh-sungguh. Jika pemeliharaan karyawan kurang diperhatikan, semangat kerja, sikap, dan loyalitas karyawan akan menurun. Pemeliharaan adalah usaha mempertahankan dan atau meningkatkan kondisi fisik, mental dan sikap karyawan, agar mereka tetap loyal dan bekerja produktif untuk menunjang tercapainya tujuan perusahaan.

Lebih lanjut dikatakan tujuan pemeliharaan adalah:

a. Untuk meningkatkan produktivitas kerja karyawan

b. Meningkatkan disiplin dan menurunkan absensi karyawan

c. Meningkatkan loyalitas dan menurunkan turnover karyawan

d. Memberikan ketenangan, keamanan, dan kesehatan karyawan

e. Meningkatkan kesejahteraan karyawan dan keluarganya

f. Memperbaiki kondisi fisik, mental, dan sikap karyawan

g. Mengurangi konflik serta menciptakan suasana yang harmonis

h. Mengefektifkan pengadaan karyawan

Sedangkan metode-metode pemeliharaan adalah:

a. Komunikasi;

b. Insentif;

c. Kesejahteraan karyawan;

d. Kesadaran dan keselamatan kerja; dan

e. Hubungan industrial (hasibuan, 2000).

\section{Faktor Penentu Retensi Karyawan}

Baik para pemberi kerja maupun para karyawan telah mengetahui bahwa beberapa bidang umum memengaruhi retensi karyawan. Berikut adalah uraian bagaimana setiap kelompok komponen mempengaruhi upaya tersebut.

\section{Komponen Organisasi}

Beberapa komponen organisasi mempengaruhi karyawan dalam memutuskan apakah bertahan atau meninggalkan pekerjaan mereka. Organisasi yang memiliki budaya dan nilai yang positif dan berbeda mengalami perputaran karyawan yang lebih rendah. Budaya organisasi adalah pola nilai dan keyakinan bersama yang memberikan 
arti dan peraturan perilaku bagi anggota organisasional. Nilai organisasional utama yang mempengaruhi keinginan karyawan untuk bertahan adalah kepercayaan. Komponen organisasi lain yang mempengaruhi retensi karyawan berhubungan dengan strategi, peluang dan manajemen organisasi. Semua pengurangan karyawan, pemberhentian sementara, merger dan akuisisi, serta penyusunan ulang organisasional telah mempengaruhi loyalitas dan retensi karyawan.

\section{Peluang Karier Organisasi}

Survei yang dilakukan AON Consulting (sebuah lembaga independen yang mengkaji loyalitas di tempat kerja) terhadap karyawan di semua jenis pekerjaan tetap menunjukkan bahwa usaha pengembangan karir organisasional dapat mempengaruhi tingkat retensi karyawan secara signifikan. Peluang untuk perkembangan pribadi memunculkan alasan mengapa individu mengambil pekerjaannya saat ini dan mengapa mereka bertahan. Usaha pengembangan karir organisasional dirancang untuk memenuhi harapan para karyawan bahwa para pemberi kerja mereka berkomitmen untuk mempertahankan pengetahuan, keterampilan, dan kemampuannya saat ini. Perencanaan karir organisasi juga meningkatkan retensi karyawan dengan mengupayakan perencanaan karir formal.

\section{Penghargaan dan Retensi Karyawan}

Banyak manajer yakin bahwa uang merupakan faktor retensi karyawan yang utama. Sekitar $89 \%$ responden dalam sebuah survei dan sebagian besar karyawan menyebutkan gaji yang lebih baik atau kompensasi yang lebih tinggi sebagai alasan untuk berpindah kerja. Akan tetapi kenyataannya sedikit lebih rumit. Persoalan lain yang mempengaruhi retensi karyawan adalah program tunjangan kompetitif dan bonus spesial, kinerja, dan kompensasi serta pengakuan.

\section{Rancangan Tugas dan Pekerjaan}

Faktor mendasar yang mempengaruhi retensi karyawan adalah sifat dari tugas dan pekerjaan yang dilakukan. Selanjutnya fleksibilitas kerja juga membantu retensi karyawan.

\section{Hubungan Karyawan}

Kumpulan faktor terakhir yang diketahui mempengaruhi retensi karyawan didasarkan pada hubungan yang dimiliki para karyawan dalam organisasi. Hubungan karyawan, termasuk perlakuan adil/tidak diskriminatif dan pelaksanaan kebijakan SDM, juga dapat meningkatkan retensi karyawan. Asas-asas umum manajemen (general principles of management) menurut Henry Fayol seperti dikutip Hasibuan menyebutkan asas kestabilan masa jabatan (stability of turn-over personnel) yang maksudnya, pimpinan perusahaan harus berusaha agar mutasi dan keluar masuknya karyawan tidak terlalu sering. Karena akan mengakibatkan ketidakstabilan organisasi, biaya- 
biaya semakin besar, dan perusahaan tidak mendapat karyawan yang berpengalaman.

\section{METODE PENELITIAN Jenis Penelitian}

Jenis penelitian ini adalah Penelitian Kuantitatif, penelitian kuantitatif yaitu salah satu metode penelitian dimana data penelitian berupa angka-angka dan analisis menggunakan statistik (Sugiyono, 2015). Oleh karena itu, penelitian kuantitatif menggunakan skala numerik berbasis pola alur deduktif, dimana untuk menjawab rumusan masalah digunakan konsep atau teori sehingga dapat dirumuskan hipotesis. Tujuannya yaitu untuk menguji hipotesis yang ditetapkan.

\section{Objek atau Lokasi Penelitian}

Menurut Sugiyono (2015) pengertian objek penelitian adalah sasaran ilmiah untuk mendapatkan sejumlah data dengan tujuan dan kegunaan tertentu tentang sesuatu hal objektif valid, dan reliable. Dengan demikian objek penelitian merupakan lokasi dimana untuk mendapatkan sejumlah data yang akan dilakukan penelitian. PT. Bank Rakyat Indonesia dijadikan sebagai objek penelitian ini yang beralamat di Jl. Adinegoro, Lubuk Buaya, Koto Tangah, Kota Padang, Sumatera Barat

\section{Populasi}

Populasi merupakan wilayah generalisasi yang terdiri atas subjek atau objek yang mempunyai kuantitas dan karakteristik tertentu yang ditetapkan oleh peneliti untuk dipelajari dan kemudian ditarik kesimpulannya (Sugiyono, 2015). Oleh karena itu, dapat disimpulkan bahwa populasi merupakan keseluruhan subjek ataupun objek yang memiliki karakteristik berbeda dan bisa diteliti atau diamati. Populasi dalam penelitian ini adalah seluruh karyawan PT.Bank Rakyat Indonesia yang berjumlah 33 orang.

Sampel

Sampel merupakan bagian dari jumlah dan karakteristik yang dimiliki oleh populasi tersebut (Sugiyono, 2015). Teknik pengambilan Sampel dilakukan dengan cara total sampling atau sampel jenuh atau juga disebut dengan sampel sensus, adalah teknik sampling yang dilakukan dengan mengambil seluruh populasi (Sugiyono, 2015). Berdasarkan populasi karyawan, maka sampel penelitian ini sebanyak 33 orang karyawan PT. Bank Rakyat Indonesia

\section{Jenis Data}

\section{Data Kualitatif}

Data Kualitatif adalah data yang berbentuk kata, kalimat, gerak tubuh, dan gambar (Sugiyono, 2015). Data yang termasuk data kualitatif dalam penelitian ini yaitu gambaran umum dari objek penelitian.

\section{Data Kuantitatif}

Data kuantitatif adalah data yang berbentuk angka-angka atau data kualitatif yang diangkakan (Sugiyono, 2015). Data yang termasuk data kuantitatif adalah jumlah karyawan, jumlah turnover karyawan dan hasil kuisioner. 


\section{Teknik Pengumpulan Data \\ Kuisioner}

Kuisioner merupakan teknik pengumpulan data yang dilakukan dengan cara memberi beberapa pertanyaan dan pernyataan tertulis kepada responden untuk dijawabnya (Sugiyono, 2015). Oleh kaena itu, pemberian beberapa pertanyaan kepada para anggota sampel (responden) disebut juga kuisioner.

\section{Interview}

Interview adalah teknik pengumpulan data dari permasalahan yang harus diteliti dan apabila ingin mengetahui hal-hal dari responden secara mendalam dan jumlah respondennya kecil (Sugiyono, 2015). Dengan demikian, interview dilakukan jika peneliti ingin mengetahui permasalahan yang muncul secara mendalam pada objek penelitian.

\section{Definisi Operasional Variabel}

\begin{tabular}{|c|c|c|}
\hline Variabel & Definisi & Indikator \\
\hline $\begin{array}{l}\text { Employee retention } \\
\text { (X) }\end{array}$ & $\begin{array}{l}\text { Kemampuan Perusahaan untuk } \\
\text { mempertahankan karyawan } \\
\text { potensial untuk tetap loyal } \\
\text { terhadap perusahaan. }\end{array}$ & $\begin{array}{l}\text { 1. Komponen organisasi } \\
\text { 2. Peluang karier } \\
\text { organisasi } \\
\text { 3. Penghargaan dan } \\
\text { retensi karyawan } \\
\text { 4. Hubungan karyawan }\end{array}$ \\
\hline $\begin{array}{l}\text { Turnover Intention } \\
\text { (Y1) }\end{array}$ & $\begin{array}{l}\text { Keadaan dimana karyawan } \\
\text { sebuah organisasi memiliki } \\
\text { perencanaan untuk } \\
\text { meninggalkan pekerjaannya, } \\
\text { atau kondisi dimana organisasi } \\
\text { memiliki rencana untuk } \\
\text { memutus hubungan kerja } \\
\text { dengan karyawannya }\end{array}$ & $\begin{array}{l}\text { 1. Adanya niat untuk } \\
\text { keluar } \\
\text { 2. Pencarian pekerjaan } \\
\text { 3. Karyawan } \\
\text { membandingkan } \\
\text { pekerjaan }\end{array}$ \\
\hline $\begin{array}{l}\text { Kinerja karyawan } \\
\text { (Y2) }\end{array}$ & $\begin{array}{l}\text { Proses organisasi menilai atau } \\
\text { mengevaluasi prestasi kerja } \\
\text { karyawan }\end{array}$ & 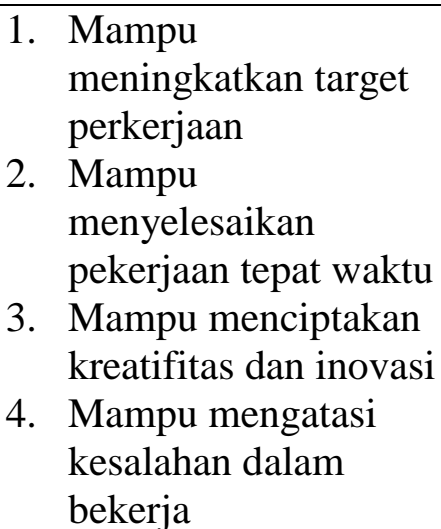 \\
\hline
\end{tabular}

\section{Teknik Analisis Data}

\section{Uji Vadilitas}

Uji vadilitas adalah suatu langkah pengujian yang dilakukan terhadap isi (konten) dari suatu instrumen yang digunakan dalam suatu penelitian (Sugiyono, 2015). Dengan demikian uji vadilitas merupakan pengukuran ketepatan atau kevalidan dalam suatu instrumen yang diukur dan suatu alat 
ukur dapat dikatakan mempunyai validitas tinggi apabila dapat dijalankan fungsi ukurnya atau memberikan hasil ukur yang sesuai dengan maksud dan tujuan dari diadakannya tes atau penilaian tersebut.

Validitas suatu butir pertanyaan dapat dilihat dari output StatisticalProgram For Social Science (SPSS) pada pada tabel dengan judul Item-Total Statistisc.Suatu butir pertanyaan dikatakan valid jika nilai dari Corrected Item-Total Corrected> 0,300. Uji validitas sebaiknya dilakukan secara terpisah pada lembar kerja yang berbeda antara satu konstruk variabel dengan konstruk variabel yang lain sehingga dapat diketahui butir-butir pertanyaan variabel mana yang paling banyak tidak valid. Sehingga pengambilan keputusan adalah:

a. Jika Corrected Item-Total Correlation> 0,300, maka dimensi tersebut valid

b. Jika Corrected Item-Total Correlation $<0,300$, maka dimensi tersebut tidak valid

\section{Uji Reliabilitas}

Uji reliabilitas adalah uji terhadap instrumen yang bila digunakan beberapa kali untuk mengukur objek yang sama akan menghasilkan data yang sama (Sugiyono, 2015). Oleh karena itu uji reliabilitas adalah penguiian yang menghasilkan data yang sama dengan melihat tingkat kosistensi dari instrumen yang diukur. . Indikator pengukuran yang digunakan adalah cronbach's alpa. Uji reabilitas dapat dilakukan secara bersama-sama terhadap seluruh butir pernyataan untuk lebih dari satu variabel, namun sebaiknya uji reliabilitas sebaliknya dilakukan pada masing - masing variabel pada lembar kerja yang berbeda sehingga dapat diketahui konstruk variabel mana yang tidak reliabel. Reliabilitas suatu konstuk variabel dikatakan baik jika memiliki nilai Cronbach's Alpha $>0,06$. Sehingga pengambilan keputusan adalah :

a. Jika $r$ Alpha positif, serta $r>0,06$ maka dimensi tersebut reliabel.

b. Jika $r$ Alpha positif, serta $r \leq 0,06$ maka dimensi tersebut tidak reliabel.

\section{Uji TCR (Tingkat Capaian Responden)}

Menurut Suharsimi (2002) total capaian responden merupakan suatu ukuran untuk menghitung masing-masing kategori jawaban dari deskriptif variabel, maka dapat dihitung dengan menggunkan rumusan:

$$
T C R=\frac{\text { Skor tiap item } X 100 \%}{\text { Skor ideal item yang dihitung }}
$$

Keterangan :

TCR $=$ Tingkat Capaian Responden

Untuk menginterprestasikan jawaban responden terhadap pertanyaa yang diajukan, sebagai acuannya tabel kriteria pengklasifikasikan ratarata jawaban responden sebagai berikut :
a. $81-100 \%=$ sangat baik
b. $61-80 \%=$ baik
c. $41-60 \%=$ kurang baik
d. $21-40 \%=$ tidak baik
e. $<20 \%=$ sangat tidak baik 


\section{Uji asumsi klasik \\ Uji Normalitas}

Uji normalitas adalah pengujian untuk mengkaji kenormalan variabel yang diteleti apakah data tersebut berdistribusi normal atau tidak (Sugiyono, 2015). Dapat disimpulkan bahwa uji normalitas untuk melihat tingkat kenormalan variabel yang diteliti. Indikator yang digunakan Uji kolmogrov-smirnov dengan pedoman yaitu :

a. Jika nilai signifikansi $>0,05$., maka berdistribusi normal

b. Jika nilai signifikans $<0,05$, maka tidak berdistribusi normal

\section{Uji Heteroskedatisitas}

Uji heteroskedastisitas yaitu untuk menguji apakah dalam model regresi terjadi ketidaksamaan variance dari residual satu pengamatan kepengamatan yang lain. Jika variance dari residual satu pengamatan kepengamatan lain tetap, maka disebut homoskedastisitas dan jika berbeda disebut heteroskedastisitas. Model regresi yang baik adalah yang homoskedastisitas atau tidak terjadi heteroskedastisitas. Jika pvalue $>0,05$ maka tidak signifikan berarti tidak terjadi heteroskedastisitas artinya model regresi lolos uji heteroskedastisitas (Ghozali, 2011).

\section{Analisis Regresi Sederhana}

Analisis regresi sederhana untuk mengetahui apakah variabel independen berpengaruh atau tidak terhadap variabel dependen, maka dapat dilihat dari taraf signifikansinya dengan standar signifikansi 5\%. Apabila tingkat signifikansi yang diperoleh dari hasil lebih besar dari 5\% maka hipotesis ditolak, sebaliknya jika hasil uji hipotesis berada diantara 0-5\% maka hipotesis diterima. Analisis regresi berganda merupakan untuk mengetahui hubungan antara variabel independen dan variabel dependen. Persamaan regresi sederhana multi variabel adalah :

$$
\begin{array}{ll}
\mathrm{Y} 1 & =\alpha+\beta \mathrm{X}+\mathrm{e} \\
\mathrm{Y} 2 & =\alpha+\beta \mathrm{X}+\mathrm{e} \\
\mathrm{X} & =\text { Employee Retention } \\
\mathrm{Y} 1 & =\text { Turnover Intention } \\
\mathrm{Y} 2 & =\text { Kinerja karyawan } \\
\alpha & =\text { Koefisien Konstanta } \\
\beta & =\text { Koefisien regresi } \\
\mathrm{e} & =\text { Standar } \text { error }
\end{array}
$$

\section{Uji Hipotesis}

\section{Uji T}

Menurut Imam Ghozali (2011) uji statistik t pada dasarnya menunjukkan seberapa jauh pengaruh satu variabel independen secara individual dalam menerangkan variabel dependen. Pengujian dilakukan dengan menggunakan signifikan level $0,05 \quad(\alpha=5 \%)$. Penerimaan atau penolakan hipotesis dilakukan dengan kriteria:

a. Jika nilai signifikan > 0,05 maka hipotesis ditolak (koefisien regresi tidak signifikan). Ini berarti secara parsial variabel independen tidak mempunyai pengaruh secara signifikan terhadap variabel dependen. 
b. Jika nilai signifikan $\leq 0,05$ maka hipotesis diterima (koefisien regresi signifikan ). Ini berarti secara parsial variabel independen tersebut mempunyai pengaruh yang signifikan terhadap variabel dependen.

\section{HASIL DAN PEMBAHASAN}

\section{Regresi Linier Sederhana}

Untuk mengetahui pengaruh employee retention terhadap turnover dan kinerja karyawan, maka dapat dikemukakan persamaan Regresi Linear Sederhana dengan melakukan pengujian sebanyak dua kali yaitu employee retention dengan turnover intention dan employee retention dan kinerja karyawan. Berikut penjelasannya sebagai berikut a. Regresi Linier Sederhana Employee terhadap Turnover Intention

\section{Tabel 1}

\section{Hasi Uji Regresi Linier Sederhana}

Coefficients(a)

\begin{tabular}{|c|c|c|c|c|c|c|}
\hline \multicolumn{2}{|c|}{ Model } & \multicolumn{2}{|c|}{$\begin{array}{l}\text { Unstandardized } \\
\text { Coefficients }\end{array}$} & \multirow{2}{*}{$\begin{array}{c}\text { Standardized } \\
\text { Coefficients } \\
\text { Beta }\end{array}$} & \multirow{2}{*}{$\begin{array}{l}\mathrm{T} \\
\mathrm{B}\end{array}$} & \multirow{2}{*}{$\begin{array}{l}\text { Sig. } \\
\text { Std. } \\
\text { Error }\end{array}$} \\
\hline & & B & Std. Error & & & \\
\hline \multirow[t]{2}{*}{1} & (Constant) & 10.759 & 6.037 & & 1.782 & .085 \\
\hline & $X$ & .418 & .161 & .423 & 2.602 & .014 \\
\hline
\end{tabular}

a Dependent Variable: $Y 1$

Berdasarkan tabel di atas dapat disubstitusikan ke dalam model estimasi sebagai berikut :

$$
\mathrm{Y} 1=10,759+0,418 \mathrm{X}
$$

Keterangan:

Y1 = Turnover Intention

$\mathrm{X}=$ Employee Retention

Dari persamaan diatas dapat dilihat bahwa terdapat nilai konstanta sebesar 10,759 yang berarti bahwa tanpa adanya employee retention terhadap turnover intention berada pada 10,759 satuan. Nilai koefisien dari variabel $X$ adalah sebesar 0,418 ini berarti bahwa meningkatnya employee retention pada satu satuan, maka akan meningkatkan turnover intention sebesar 0,418 .

b. Regresi Linier Sederhana Employee Retention terhadap Kinerja Karyawan

Tabel 2

Hasi Uji Regresi Linier Sederhana Coefficients(a)

\begin{tabular}{|c|c|c|c|c|c|c|}
\hline \multicolumn{2}{|c|}{ Model } & \multicolumn{2}{|c|}{$\begin{array}{l}\text { Unstandardized } \\
\text { Coefficients }\end{array}$} & \multirow{2}{*}{$\begin{array}{c}\text { Standardized } \\
\text { Coefficients } \\
\text { Beta } \\
\end{array}$} & \multirow{2}{*}{$\begin{array}{l}\mathrm{T} \\
\mathrm{B} \\
\end{array}$} & \multirow{2}{*}{$\begin{array}{l}\text { Sig. } \\
\text { Std. } \\
\text { Error }\end{array}$} \\
\hline & & $B$ & Std. Error & & & \\
\hline \multirow[t]{2}{*}{1} & (Constant) & 9.698 & 5.905 & & 1.642 & .111 \\
\hline & $X$ & .680 & .157 & .613 & 4.320 & .000 \\
\hline
\end{tabular}


Berdasarkan tabel di atas dapat disubstitusikan ke dalam model estimasi sebagai berikut :

$$
\mathrm{Y} 1=9,698+0,680 \mathrm{X}
$$

Keterangan:

Y2 = Kinerja Karyawan

$\mathrm{X}=$ Employee Retention

Dari persamaan diatas dapat dilihat bahwa terdapat nilai konstanta sebesar 9,698 yang berarti bahwa tanpa adanya employee retention terhadap kinerja karyawan berada pada 9,698 satuan. Nilai koefisien dari variabel $X$ adalah sebesar 0,680 ini berarti bahwa meningkatnya employee retention pada satu satuan, maka akan meningkatkan kinerja karyawan sebesar 0,680.

\section{Pengujian Hipotesis}

Dengan melihat dari hasil regresi sederhana maka peneliti akan melakukan pengujian hipotesis yang mana disebutkan bahwa apabila nilai signifikan > 0,05 maka hipotesis ditolak (koefisien regresi tidak signifikan) dan apabila nilai signifikan $\leq 0,05$ maka hipotesis diterima (koefisien regresi signifikan ). Melalui tabel 3 akan menujukan nilai hipotesis berdasarkan dari hasil regresi sebagai berikut:

Tabel 3

Hasil Uji Hipotesis

\begin{tabular}{|c|c|c|}
\hline Regresi & Sig & Keterangan \\
\hline $\mathrm{Y} 1=\alpha+\beta \mathrm{X}+\mathrm{e}$ & 0,014 & H1 diterima \\
\hline $\mathrm{Y} 2=\alpha+\beta \mathrm{X}+\mathrm{e}$ & 0,000 & H2 diterima \\
\hline
\end{tabular}

Sumber : data diolah, 2018

Berdasarkan tabel menjelaskan bahwa nilai sig pada hasil regresi menunjukan >0,05 yaitu 0,014 dan 0,000. Maka dapat disimpulkan bahwa hipotesis yang disiapkan oleh peneliti dapat diterima sebagaimana hipotesis disebutkan sebagai berikut:

H1 : employee retention berpengaruh positif dan signifikan terhadap turnover intention karena adanya fenomena yang menyebabkan karyawan tetap memilih keluar dari perusahaan

H2 : employee retention berpengaruh positif dan signifikan terhadap kinerja karyawan

\section{Pembahasan}

\section{Pengaruh Employee Retention Terhadap Turnover Intention}

Employee retention merupakan hal penting perlu dilakukan perusahan agar pengeluaran suatu perusahaan akan sedikit berkurang seperti halnya pada PT. Bank Rakyat Indonesia cabang Lubuk Buaya yang telah melakukan employee retention. Oleh sebab itu melalui hasil uji T yang dilakukan peneliti yang dilakukan di PT. Bank Rakyat Indonesia cabang Lubuk Buaya melalui hipotesis pertama, maka peneliti mengambil kesimpulan bahwa pengaruh employee retention terhadap turnover intention signifikan dan positif karena nilai sig adalah 0,033. Tujuan dari Employee Retention ialah untuk 
mempertahankan karyawan yang dianggap berkualitas yang dimiliki perusahaan selama mungkin, karena karyawan yang berkualitas merupakan harta yang tidak tampak (intangible asset) yang tak ternilai bagi perusahaan.

\section{Pengaruh Employee Retention Terhadap Kinerja Karyawan}

Selanjutnya employee retention merupakan hal yang penting dalam kinerja karyawan sebagaimana hasil dari regresi yang dilakukan oleh peneliti melalui hipotesis kedua dapat disimpulkan bahwa pengaruh employee retention terhadap kinerja karyawan signifikan dan positif karena nilai sig adalah 0,000. Sebagaimana menurut (Mangkunegara, 2009) Pengelolaan karyawan yang baik dan berkelanjutan akan meningkatkan kepuasan kerja. Kinerja merupakan suatu hasil dan usaha seseorang yang dicapai dengan adanya kemampuan seseorang dan perbuatan dalam situasi tertentu.

\section{SIMPULAN}

Penelitian ini, bertujuan untuk mengetahui Pengaruh Employee Retention Terhadap Turnover Intention dan Kinerja Karyawan, dengan menggunakan sampel 33 orang responden pada PT. Bank Rakyat Indonesia Cabang Lubuk Buaya. Berdasarkan hasil analisis tentang Pengaruh Employee Retention terhadap Turnover Intention dan Kinerja Karyawan dapat disimpulkan sebagai berikut:

1. Pengaruh Employee Retention Terhadap Turnover Intention Employee Retention berpengaruh positif dan signifikan terhadap turnover intention, hal tersebut ditunjukan terhadap hasil regresi linier sederhana bahwa nilai sig menunjukan 0,033 yang berarti > 0,05 .

2. Pengaruh Employee Retention Terhadap Kinerja Karyawan

Employee Retention berpengaruh positif dan signifikan terhadap kinerja karyawan, hal tersebut ditunjukan terhadap hasil regresi linier sederhana bahwa nilai sig menunjukan 0,000 yang berarti $>0,05$.

\section{DAFTAR PUSTAKA}

Ajzen, I. (2005). Attitudes, personality, and behavior. New York: University Press.

Amelia, A. (2010). Pengaruh Work-to-family conflict dan familt-to-work conflict terhadap kepuasan dalam bekerja,keinginan pindah tempat kerja, dan kinerja karyawan. Jurnal Ekonomi Dan Bisnis, 4 No.3.

Arikunto, S. (2010). Prosedur Penelitian Suatu Pendekatan Praktis. Jakarta: PT. Rineka Cipta.

ELizabeth, M. (2012). Job Satisfaction \& Employee Turnover Intention: What Does Organizational Culture have to do with It. Columbia University. 
Fendi, Z., \& Susanti, F. (2018). Pengaruh Kepuasan Kerja Terhadap Turnover Intention Dengan Komitmen Organisasi Sebagai Variabel Intervening Pada CV. Belibis Pariaman. https://doi.org/10.31227/osf.io/wumgx

Ghozali, I. (2011). Aplikasi Analisis Multivariate Dengan Program IBM SPSS 20. In book (pp. 1-298). Semarang: Badan Penerbit Universitas Diponegoro.

Gomes, F. C. (2000). Manajemen Sumber Daya Manusia. Yogyakarta: Andi Offset.

Guritno, B., \& Waridin. (2005). Pengaruh Persepsi Karyawan Mengenai Perilaku Kepemimpinan, Kepuasan Kerja Dan Motivasi Terhadap Kinerja. JRBI, 1 No.1, 63-74.

Handoko, T. H. (2002). Manajemen (Kedua). Yogyakarta: BPFE.

Hasibuan, M. S. . (2007). Manajemen Sumber Daya Manusia Perusahaan. Bandung: Bumi Aksara.

Henry, S. (2004). Manajemen Sumber Daya Manusia. Yogyakarta: STIE YPKN.

Mangkunegara, A. P. (2009). Manajemen Sumber Daya Manusia. Bandung: PT. Remaja Rosdakarya.

Mayliza, R. (2019). Pengaruh Stres Kerja Dan Kesempatan Promosi Terhadap Turnover Intention Pada CV. Anisa Fadly Kabupaten Padang Pariaman. https://doi.org/10.17605/OSF.IO/PCDV2

Robbins, S. (2003). Perilaku Organisasi (alih bahasa Drs. BenjaminMolan (Bahasa Ind). Klaten: PT INT AN SEJATI.

Safi'i, S. Z. (2015). Pengaruh Budaya Organisasi dan Komitmen Organisasi terhadap Turnover Karyawan pada PT. Massindo Sinar Pratama. TBK Manado, 3(1), 642-652.

Saputra, B. (2017). Pengaruh Budaya Organisasi, Kompensasi Non Finansial dan Job Insecurity terhadap Turnover Intention PT. Parit Padang Pekanbaru, $4(1), 806-815$.

Sopiah, S. (2008). Manajemen Bisnis Ritel. Yogyakarta: Andi Offset.

Sugiyono. (2015a). Metode Penelitian Pendidikan (Pendekatan Kuantitatif, Kualitatif dan $R \& D)$. Bandung: Alfabeta.

Sugiyono. (2015b). Statistik Nonparametris Untuk Penelitian. Book. Band 
CV. Alvabeta.

Swietenia, R. (2009). Analisis Pengaruh Kepemimpinan, Kompensasi dan Karakteristik Pekerjaan Terhadap Disiplin Kerja Serta Implikasinya Terhadap Kinerja Pegawai (Studi Pada Kantor Pertanahan Kota Semarang). Jurnal Ekonomi - Manajemen - Akuntansi, 96-116.

Winardi. (2003). Teori Ekonomi Mikro. Jakarta: Transito. 